\title{
A Contribution to the Taxonomy and Ecology of Shrews (Crocidura zimmermanni and C. suaveolens) from Crete and Turkey
}

\author{
Peter VOGEL, Tiziano MADDALENA \& François CATZEFLIS
}

\begin{abstract}
Vogel P., Maddalena T. \& Catzeflis F., 1986: A contribution to the taxonomy and ecology of shrews (Crocidura zimmermanni and C. suaveolens) from Crete and Turkey. Acta theriol., 31, 39: 537-545 [With 4 Tables \& 1 Fig.]

Chromosomal and biochemical investigations of shrews from the genus Crocidura from Crete and Turkey show that C. russula monacha Thomas, 1906 and C caneae Miller, 1909 are both members of the species C. suaveolens Pallas, 1811. C. russula zimmermanni Wettstein, 1953 is a well defined species: C. zimmermanni Wettstein, 1953. The populations of $C$. suaveolens in Crete, whose presence on the island dates from at least 3500 year b.p. is biochemically very similar to those of C. suaveolens from Turkey. The same set of electrophoretic data suggests that $C$. suaveolens from Cyprus became isolated from mainland populations much earlier. $C$. zimmermanni shows closer phylogenetic relationships with C. leucodon and C. suaveolens, than with C. russula. Endemic in Crete, C. zimmermanni is syntopic with C. suaveolens at medium and high altitudes, but has been eliminated by the latter in the fertile lowland plains.

[Institute of Zoology and Animal Ecology, University of Lausanne, $\mathrm{CH}-1015$ Lausanne, Switzerland]
\end{abstract}

\section{INTRODUCTION}

On the Meditteranean island of Crete, two taxa of the genus Crocidura have been described: Crocidura caneae Miller, 1909 and C. russula zimmermanni Wettstein, 1953. Twenty one shrews were recently collected from three localities on Crete, by one of the authors (P.V.). Of these, four specimens have revealed an unknown karyotype (Vogel, 1986). This result has allowed us to demonstrate specific rank of the second taxon, C. zimmermanni, confirming the views of Vesmanis and Kahmann (1978), Pieper (1978) and Reumer (in press). Based on their morphology, the remaining 18 specimens can be attributed to the form caneae, which is considered by Wettstein (1953) and Ellerman and Morrison-Scott (1966) to be a subspecies of C. russula, by Richter (1970), Pieper (1978), and Vesmanis and Kahmann (1978), to be a subspecies of C. gueldenstaedti, and by Hutterer (1981) to be a subspecies of C. suaveolens. Finally, Kock (1973) determined a sample of shrews from low altitude as 
mixed (not hybrid) population of C. gueldenstaedti and C. suaveolens.

The primary aim of the present paper is to analyse the chromosomes of the form caneae. As this karyotype turns out to be similar to that of a well-known continental species, we question whether, in fact, the geographical isolation of this island has led to a speciation, without affecting the gross morphology of the chromosomes. Therefore, we add to our morphological and chromosomal investigation a biochemical analysis of a set of isoenzymes assayed by electrophoresis. This approach will demonstrate the presence of distinct, fixed electromorphs in each taxon and also allows us to quantify the level of protein divergence between populations and species by interpreting the allelic frequencies into genetic distances (according to Nei, 1978).

The present biochemical analysis compares samples of shrews from Crete with standard populations of 3 species from the Continent and Cyprus, moreover, and includes several samples from Turkey, which were previously known as Crocidura russula monacha Thomas, 1906. Animals from the type locality of monacha are nevertheless characterized by a karyotype similar to that of C. suaveolens (Catzeflis et al. 1985) but their biochemical affinities remain to be defined. On Mediterranean islands, the presence of two congeneric shrews is very rare (Hutterer, 1981). Therefore, we include finally some ecological data concerning this particular situation.

\section{MATERIAL AND METHODS}

The shrews from Crete, except the specimen of Phaestos caught by M. Gyger in 1980, have been trapped in July and August 1985.

Table 1

White-toothed shrews of Crete. HB: head and body length; T: tail length; HF: hind foot length; W: weight; CBL: condylobasal length; RL: rostral length. Mean values and their sample-standard deviation. Chrom./Bioch.: animals examined chromosomally and/or biochemically.

\begin{tabular}{|c|c|c|c|c|c|c|c|c|c|c|}
\hline Locality & Species & $\mathrm{N}$ & HB & $\mathrm{T}$ & $\mathrm{HF}$ & $\mathrm{w}$ & CBL & RL & Chrom. & Biol. \\
\hline Mallia & C. suaveolens & 9 & $\begin{array}{l}70.1 \\
\pm 3.1\end{array}$ & $\begin{array}{r}52.2 \\
\pm 2.2\end{array}$ & $\begin{array}{l}12.6 \\
\pm 0.5\end{array}$ & $\begin{array}{c}7.2 \\
\pm 1.3\end{array}$ & $\begin{array}{l}18.60 \\
\pm 0.44\end{array}$ & $\begin{array}{l}2.74 \\
\pm 0.10\end{array}$ & 5 & - \\
\hline Phaistos & C. suaveolens & 1 & 73.0 & 41.0 & 11.2 & 6.3 & 17.99 & 2.39 & 1 & - \\
\hline Platanias & C. suaveolens & 8 & $\begin{array}{l}71.3 \\
\pm 2.1\end{array}$ & $\begin{array}{r}46.6 \\
\pm 2.0\end{array}$ & $\begin{array}{l}12.3 \\
\pm 0.4\end{array}$ & $\begin{array}{l}6.9 \\
\pm 0.7\end{array}$ & $\begin{array}{l}18.19 \\
\pm 0.28\end{array}$ & $\begin{array}{l}2.69 \\
\pm 0.09\end{array}$ & 2 & 3 \\
\hline $\begin{array}{l}\text { Idhi } \\
\text { mountair }\end{array}$ & $\begin{array}{l}\text { C. suaveolens } \\
\text { s C. zimmermanni }\end{array}$ & $\begin{array}{c}1 \\
1\end{array}$ & 64.0 & 52.0 & 12.0 & 5.5 & 18.04 & 2.38 & 1 & 1 \\
\hline Omalos & C. zimmermanni & 2 & $\begin{array}{l}73.0 \\
\pm 2.2\end{array}$ & $\begin{array}{r}40.3 \\
\pm 0.9\end{array}$ & $\begin{array}{l}13.0 \\
\pm 0.0\end{array}$ & $\begin{array}{l}7.7 \\
\pm 0.5\end{array}$ & $\begin{array}{l}20.14 \\
\pm 0.17\end{array}$ & $\begin{array}{l}3.25 \\
\pm 0.04\end{array}$ & 3 & 3 \\
\hline
\end{tabular}


The geographical origin, sample size, morphological characteristics and type of analysis (chromosomal and/or biochemical) of the animals are given in Tabie 1

Karyotypes were prepared according to the techniques described in Meylan (1967) and Baker et al. (1982). Tissue samples (liver, heart and kidneys) of each individual were preserved in liquid nitrogen and the electrophoretic analysis was carried out following the techniques described, or cited, in Catzeflis et al. (1985). In the present paper, isoenzymes encoded by 26 presumptive loci have been assayed.

The geographical origin, the karyotype and the measurements of the shrews from Turkey have already been published by Catzeflis et al. (1985). In the present paper we analyse tissues of specimens from Maçka (the type-locality of the so-called C. russula monacha, $\mathrm{n}=8)$, Izmir $(\mathrm{n}=5)$, Rize $(n=6)$, and Kavak $(n=4)$. Reference sample of C. russula (from Switzerland), C. suaveolens (from Switzerland, Greece and Cyprus) and C. leucodon (frc Italy) have been described previously (Catzeflis 1983a, b, 1984; Catzeflis et al., 1985) and are given in Table 2.

Table 2

Origin of the 11 samples included in the biochemical analysis. ${ }^{1}$ : reference samples, previously described by Catzeflis (1983a, b).

\begin{tabular}{lccl}
\hline Species & Population & Sample size & \multicolumn{1}{c}{ Origin } \\
\hline C. russula & Cru-1 & 20 & Morges, Switzerland \\
C. leucodon & Cle-1 $^{1}$ & 6 & Serramazzoni, Italy \\
C. zimmermanni & Czim-1 $^{-1}$ & 3 & Crete, Greece \\
C. suaveolens & Csu-1 & 4 & Thessaloniki, Greece \\
& Csu-2 & 5 & Mendrisio, Switzerland \\
& Csu-3 & 4 & Kavak, Turkey \\
& Csu-4 & 5 & Izmir, Turkey \\
& Csu-5 & 6 & Rize, Turkey \\
& Csu-6 & 8 & Maçka, Turkey \\
& Csu-7 & 4 & Crete, Greece \\
& Csu-8 1 & 5 & Laxla, Cyprus \\
\hline
\end{tabular}

\section{RESULTS}

\subsection{Chromosomal Analysis}

In Crete, 3 of the 12 shrews for which karyotypes were prepared yielded an original chromosomal set of $2 \mathrm{n}=34, \mathrm{NF}=44, \mathrm{NFa}=40$ (as described and illustrated in Vogel, 1986), suggesting specific rank of C. zimmermanni. The remaining individuals which have so far been examined possess a karyotype of $2 \mathrm{n}=40, \mathrm{NF}=50, \mathrm{NFa}=46$. This chromosomal complement and its gross morphology is identical to that of C. suaveolens as described by Meylan (1966), Meylan and Hausser (1974), 
and Catzeflis (1983a). It is also the karyotype found in all of the afore mentioned samples from Turkey (Catzeflis et al. 1985).

\subsection{Biochemical Analysis}

The allelic frequencies of the seven polymorphic loci in the samples from Crete and Turkey are presented in Table 3. Among the 19 remaining loci, seven are polymorphic in the reference samples only (those denoted in Table 2). Finally, the 12 following loci are monomorphic in every geographical sample of shrews: Aat-1 and -2, Adh, Ck-1, Hbb, Icd-1, Lap, Ldh-1, Mdh-1 and -2, Pgm and Sod-8.

Table 3

Allelic frequencies of the seven polymorphic loci in the samples of Crocidura zimmermanni and C. suaveolens of Turkey and Crete.

\begin{tabular}{lccccccc}
\hline $\begin{array}{l}\text { Population } \\
\text { Genomes }\end{array}$ & assayed & $\begin{array}{c}\text { Czim-1 } \\
(6)\end{array}$ & $\begin{array}{c}\text { Csu-3 } \\
(8)\end{array}$ & $\begin{array}{c}\text { Csu-4 } \\
(10)\end{array}$ & $\begin{array}{c}\text { Csu-5 } \\
(12)\end{array}$ & $\begin{array}{c}\text { Csu-6 } \\
(16)\end{array}$ & $\begin{array}{c}\text { Csu-7 } \\
(8)\end{array}$ \\
\hline Locus & Allele & & & & & & \\
Acp & +520 & 1.0 & 0.0 & 0.0 & 0.0 & 0.0 & 0.0 \\
& +646 & 0.0 & 1.0 & 1.0 & 1.0 & 1.0 & 1.0 \\
Alb & +93 & 1.0 & 0.0 & 0.0 & 0.0 & 0.0 & 0.0 \\
& +102 & 0.0 & 1.0 & 1.0 & 1.0 & 1.0 & 1.0 \\
Gdh & +34 & 0.0 & 0.0 & 0.20 & 0.17 & 0.0 & 0.0 \\
& +170 & 1.0 & 1.0 & 0.40 & 0.66 & 1.0 & 1.0 \\
& +184 & 0.0 & 0.0 & 0.40 & 0.17 & 0.0 & 0.0 \\
Gpi & -41 & 1.0 & 0.0 & 0.0 & 0.0 & 0.0 & 0.0 \\
& -77 & 0.0 & 1.0 & 1.0 & 1.0 & 1.0 & 1.0 \\
Me & -113 & 0.0 & 0.87 & 1.0 & 1.0 & 1.0 & 1.0 \\
& -128 & 0.0 & 0.13 & 0.0 & 0.0 & 0.0 & 0.0 \\
& -132 & 1.0 & 0.0 & 0.0 & 0.0 & 0.0 & 0.0 \\
6-Pgd & +42 & 0.0 & 1.0 & 1.0 & 1.0 & 1.0 & 1.0 \\
& +76 & 1.0 & 0.0 & 0.0 & 0.0 & 0.0 & 0.0 \\
Sod-9 & +81 & 1.0 & 0.0 & 0.0 & 0.0 & 0.0 & 0.0 \\
& +100 & 0.0 & 1.0 & 1.0 & 1.0 & 1.0 & 1.0 \\
\hline
\end{tabular}

Table 4

Standard genetic distances between samples, calculated according to Nei (1978). Abreviations as in Table 2.

\begin{tabular}{|c|c|c|c|c|c|c|c|c|c|c|}
\hline & Cru-1 & $\mathrm{Cle}-1$ & Czim-1 & Csu-1 & Csu-2 & Csu-3 & Csu-4 & Csu-5 & Csu-6 & Csu-7 \\
\hline Cle-1 & .366 & & & & & & & & & \\
\hline Czim-1 & .550 & .376 & & & & & & & & \\
\hline Csu-1 & .602 & .286 & .365 & & & & & & & \\
\hline Csu-2 & .505 & .228 & .335 & .142 & & & & & & \\
\hline Csu-3 & .489 & .262 & .257 & .112 & .087 & & & & & \\
\hline Csu-4 & .510 & .280 & .279 & .103 & .083 & .009 & & & & \\
\hline Csu-5 & .496 & .272 & .269 & .106 & .085 & .002 & .000 & & & \\
\hline Csu-6 & .485 & .267 & .262 & .117 & .092 & .000 & .009 & .002 & & \\
\hline Csu-7 & .485 & .267 & .262 & .117 & .092 & .000 & .009 & .002 & .000 & \\
\hline Csu-8 & .592 & .298 & .386 & .119 & .187 & .135 & .135 & .135 & .140 & .140 \\
\hline
\end{tabular}


Electrophoretic zymograms show that the insular sample of caneae and the Turkish samples of monacha share the same fixed electromorphs, typical of $C$. suaveolens. Furthermore, the animals referred to as $C$. zimmermanni are characterized by several particular alleles: $\mathrm{Alb}^{+93}$, $\mathrm{Gpi}^{-41}, \mathrm{Me}^{-132}, 6-\mathrm{Pgd}^{+76}$, Sod- $9^{+84}$. The genetic distances, calculated after Nei (1978) and based on the observed allelic frequencies, are summarized in Table 4 . From this, a strong relationship $(D=0.003)$ between the forms caneae and monacha is apparent, whereas C. zimmermanni takes a distant position towards caneae and monacha $(D=0.267 \pm 0.008, n=5)$ and also towards the whole set of populations so far examined $(D=0.334$ $\pm 0.092, n=10$ ). When clustered in a dendrogram, according to the UPGMA procedure (Sneath \& Sokal, 1973), the relationships based on Eenetic distances are evident (Fig. 1). The samples of monacha from

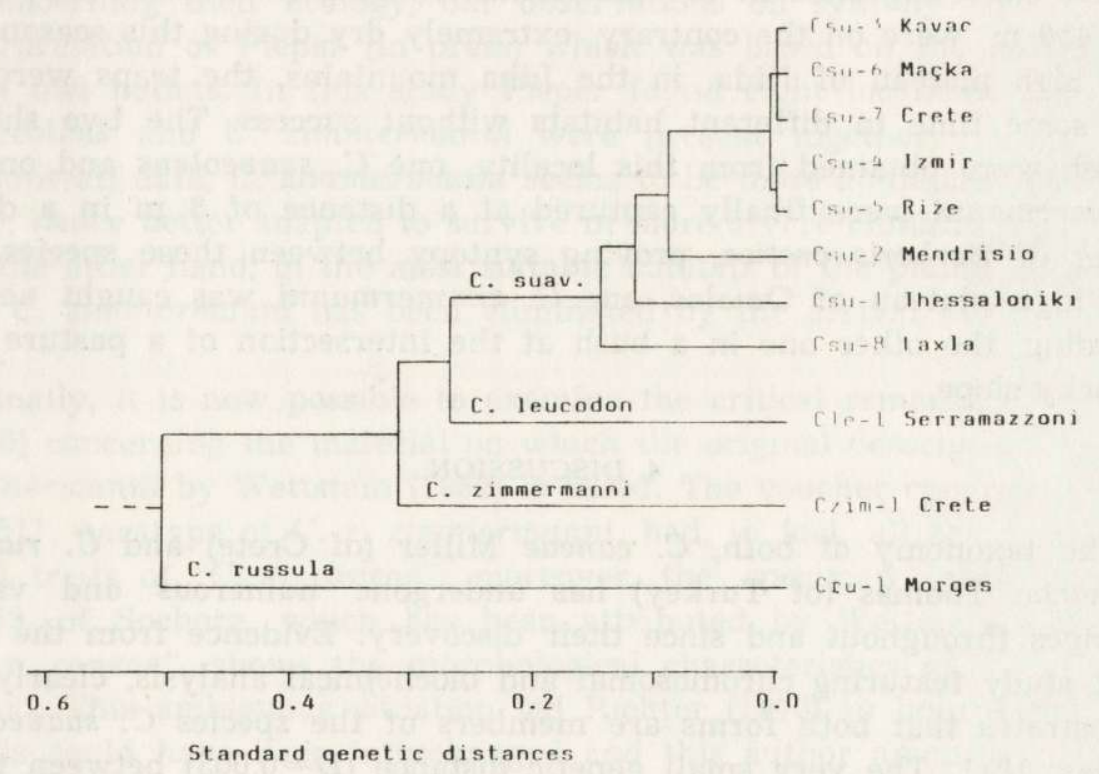

Fig. 1. Dendrogram based on the genetic distances between the populations of the four species of Crocidura, constructed according to the UPGMA procedure. The coefficient of cophenetic correlation is 0.982 . Abreviations as in Tab. 2.

Turkey and caneae from Crete are confirmed as members of the species C. suaveolens, and also seem to be more closely related to each other than to the geographical samples of Greece, Cyprus and Switzerland, all of which belong to the same species (C. suaveolens) (Fig. 1).

The specific identity of C. zimmermanni, as already shown chromosomally, is enhanced by the great genetic distances between in and the other species of Crocidura. 


\subsection{Ecological Data (Shrews of Crete)}

At low altitudes, near the locality of Mallia, most of the shrews were vaught in melon fields and in banana greenhouses. Although the season was dry (July/August), moist places were abundant due to the high density of wells and artificial irrigation (where the famous, old, custom-built windmills have been replaced by motor pumps). This aspect was lllustrated by the high population of green toads (Bufo viridis): in the region we encountered 16 active specimens along a trap line of $100 \mathrm{~m}$. The density of small mammals was also high, the most successful night with 30 traps yielded 4 C. suaveolens and 13 Mus sp. In the locality of Platanias near Chania, also at a low altit de, shrews were caught in cedges of Arundo donax and Rubus sp. which separated market gardens.

The collecting sites in the mountains, ranging in altitude from 1050 to $1450 \mathrm{~m}$, were on the contrary, extremely dry during this season. On the high plateau of Nida, in the Idha mountains, the traps were set for some time in different habitats without success. The two shrews which were obtained from this locality, one C. suaveolens and one $C$. zimmermanni were finally captured at a distance of $3 \mathrm{~m}$ in a dense cover of Berberis cretica, proving syntopy between these species. On the high plateau of Omalos, one $C$. zimmermanni was caught near a building, the other one in a bush at the intersection of a pasture and a rocky slope.

\section{DISCUSSION}

The taxonomy of both, C. caneae Miller (of Crete) and C. russula monacha Thomas (of Turkey) has undergone numerous and varied changes throughout and since their discovery. Evidence from the present study featuring chromosomal and biochemical analysis, clearly demonstrates that both forms are members of the species $C$. suaveolens Pallas, 1811. The very small genetic distance $(D=0.003)$ between these two forms suggests an integration of caneae with the subspecies $C$. suaveolens monacha Thomas, 1906 of the Turkish mainland. This interpretation should be tested by a detailed morphological investigation.

The biochemical analysis of the 3 animals referred to as C. zimmermanni Wettstein, 1953 confirms the specific status of this taxon which was previously proposed by Vesmanis and Kahmann (1978), Pieper (1978 and in press) based on morphology and by Vogel (1986) based on the chromosome complement. The genetic distances suggest a common origin with $C$. leucodon and $C$. suaveolens (eastern or asiatic species) whereas C. russula is more separate (and probably of western or north-west African origin). 
From a zoogeographical point of view, the presence of two species of the genus Crocidura on a Mediterranean island presents an exceptional situation, as Hutterer (1981), Catalan (1984) and Poitevin (1984) have previously stated. The study on fossils by Reumer (in press) and Reumer et al. (in press) shows that C. zimmermanni already occupied Crete during the Pleistocene, whereas fossils referred to as $C$. suaveolens appear only since the Minoan period $(1.500 \mathrm{BC})$. This latter species has obviously been introduced by human activity. Our data suggest that C. suaveolens which were brought into Crete arrived from Turkey and not from Greece. The same set of genetic distances also indicates that shr, is from Cyprus (C. suaveolens cypria Bate, 1903) were isolated from Turkish populations long before this time or have another geographical origin.

Concerning their ecology, our observations on synt py confirm the interpretation of Pieper (in press) which was based on the analysis of barn owl pellets. In this study Pieper found eight localities where $C$. siaveolens and $C$. zimmermanni were present together. Taking into account all data, C. zimmermanni seems to be more abundant with alti$\mathrm{t}$ de, hence better adapted to survive in more severe climatic conditions. On the other hand, in the most suitable habitats of the plains, the endemic $C$. zimmermanni has been eliminated by the arrival of $C$. suaveolens.

Finally, it is now possible to examine the critical remarks of Richter (1970) concerning the material on which the original description of $C$. $r$. zimmermanni by Wettstein (1952) is based. The voucher cpecimen NMW B 5511, paratype of C. r. zimmermanni, had, in fact, all the morphological traits of " $C$. $r$. caneae"; moreover, the specimen labelled $Z M B$ 92663, of Sochora, which has been attributed by Wettstein (1953) to "C. $r$. caneae", shows the morphological characteristics of C. zimmermanni. This ambiguous situation led Richter (1970) to believe that the labels could have been interchanged and this author amended them.

Thus, in the view of the fact that the taxa are not altitudinal races, as interpreted by Wettstein (1953), but syntopic species, even in the type locality of zimmermanni, we are convinced that the original labels had not been inversed as Richter (1970) believed, but the two specimens had simply been incorrectly identified at the onset.

Acknowledgements: We thank Dr. M. Gyger (Lausanne) for the specimen brought from Phaestos. We are indebted to Dr. J. Reumer (Geneva) and Dr. H. Pieper (Kiel) for having provided us with their papers beione publication. They and Dr. $R$. Hutterer (Bonn) were helpful with their comments on earlier drafts of this paper. We also acknowledge the technical assistance of $\mathrm{R}$. Gander and M. Mehmeti. 


\section{REFERENCES}

1, Baker R. J., Haiduk M. W., Robbins L. W., Cadena A. \& Koop B. F., 1982: Chromosomal studies of South American bats and their systematic implications. Special Publ. Pymatuning Lab. Ecol., 6: 303-327.

2. Catalan J., 1984: Application de méthodes génétiques à la systématique des Musaraignes (Soricidés) de l'Europe méridionale. Montpellier: Diplôme Ecole Pratique Hautes Etudes (Science Vie Terre).

3. Catzeflis F., 1983a: Relations génétiques entre trois espèces du genre Crocidura (Soricidae, Mammalia) en Europe. Mammalia, 47: 229-236.

4. Catzeflis F. 1983b: Analyse cytologique et biochimique des Crocidures de l'lle de Chypre (Mammalia, Insectivora). Rev. suisse Zool., 90: 407-415.

5. Catzeflis F., 1984: Différenciation génétique entre population des espèces Neomys fodiens et $N$. anomalus par électrophorèse des protéines (Mammalia, Soricidae). Rev. suisse Zool., 91: 835-850.

6. Catzeflis F., Maddalena T., Hellwing S. \& Vogel P., 1985: Unexpected findings on the taxonomic status of east Mediterranean Crocidura russula auct. (Mammalia, Insectivora). Z. Säugetierkunde, 50: 185-201.

7. Hutterer R., 1981: Der Status von Crocidura ariadne Pieper, 1979 (Mammalia: Soricidae). Bonn. zool. Beitr. 32: 3-12.

8. Kock D., 1974: Zur Säugetierfauna der Insel Chios, Aegäis (Mammalia). Senckenbergiana Biol., 55: 1-19.

9. Meylan A., 1966: Données nouvelles sur les chromosomes des Insectivores européens. Rev. suisse Zool., 73: 548-558.

10. Meylan A., (1967): Formules chrosomiques et polymorphismes robertsonien chez Blarina brevicauda (Say) (Mammalia: Insectivora). Can. J. Zool., 45: 1119$-1127$.

11. Meylan A. \& Hausser J., 1974: Position cytotaxonomique de quelques musaraignes du genre Crocidura au Tessin (Mammalia, Insectivora). Rev. suisse Zool., 81: 701-710.

12. Ellerman J. R. \& Morrison-Scott T. C. S., 1966: Checklist of Palaearctic and Indian Mammals 1758 to 1946. London: Brit. Mus. (Nat. Hist.).

13. Nei M., 1978: Estimation of average heterozygosity and genetic distance from a small number of individuals. Genetics, 89: 583-590.

14. Pieper H. 1978: Eine neue Crocidura-Art (Mammalia: Soricidae) von der Insel Kreta. Bonn. zool. Beitr., 29: 281-286.

15. Pieper H. (in press): Crocidura zimmermanni Wettstein, 1953 - Kretaspitzmaus. In: Handbuch der Säugetiere Europas, Ed. J. Niethammer u. F. Krapp. Akad. Verlagsgesellschaft, Wiesbaden, Band. 3.

16. Poitevin F., 1934: Biogéographie et écologie des Crocidures méditerranéennes (Insectivores, Soricidés) Crocidura russula (Hermann, 1780) et Crocidura suaveolens (Pallas, 1811). Importance de la compétition interspécifique dans la compréhension de leurs distributions. Thèse, Univ. Sci. Techn. Languedoc: Montpellier.

17. Reumer J. W. F., 1986: Notes on the Soricidae (Insectivora, Mammalia) from Crete. I. The Pleistocene species Crocidura zimmermanni. Bonn. zool. Beitr., 37: $161-171$.

18. Reumer J. W. F. \& Payne S., 1986: Notes on the Soricidae (Insectivora, Mammalia) from Crete. II. The shrew remains from Minoan and classical Kommos. Bonn. zool. Beitr., 37: 173-182. 
19. Richter H., 1970: Zum Taxonomischen Status der zwei Crocidura-Formen von Kreta (Mammalia, Insectivora, Soricidae). Zool. Abh. Mus. Tierkunde Dresden, 31: $279-291$.

20. Vesmanis I. \& Kahmann H., 1978: Morphometrische Untersuchungen an Wimperspitzmäusen (Crocidura) 4. Bemerkungen über die Typusreihe der kretaischen Crocidura russula zimmermanni Wettstein, $1953 \mathrm{im}$ Vergleich mit Crocidura gueldenstaedti caneae (Miller, 1909). Säugetierkdl. Mitt. 26: 214-222 .

21. Vogel P., 1986: Der Karyotyp der Kretaspitzmaus, Crocidura zimmermanni Wettstein, 1953 (Mammalia, Insectivora). Bonn. zool. Beitr., 37: 2-3.

22. Wettstein O., 1953: Die Insectivora von Kreta. Z. Säugetierk., 17: 4-13.

Accepted, April 14, 1986.

Peter VOGEL, Tiziano MADDALENA i François CATZEFLIS

\section{BADANIA NAD TAKSONOMIĄ I EKOLOGIĄ OWADOŻERNYCH Z KRETY I TURCJI (CROCIDURA ZIMMERMANNI I C. SUAVEOLENS)}

\section{Streszczenie}

Chromosomowe $\mathrm{i}$ biochemiczne badania owadożernych $\mathrm{z}$ rodzaju Crocidura z Krety i Turcji wykazały, że Crocidura russula monacha Thomas, 1906 i C. caneae Miller, 1909 przynależą do gatunku C. suaveolens Pallas, 1811. C. russula zimmermanni Wettstein, 1953 jest dobrze wyróżniającym się gatunkiem C. zimmermanni Wettstein, 1953. Populacje C. suaveolens na Krecie bytujące tam już około 3500 lat temu są biochemicznie bardzo podobne do populacji tego gatunku z Turcji. Takie same badania elektroforetyczne nad C. suaveolens z Cypru wykazały, że populacje te izolowane były od lądu dużo wcześniej. Gatunek C. zimmermanni wykazal większe filogenetyczne podobieństwo z C. leucodon i C. suaveolens, niż z C. russula. Endemiczny na Krecie C. zimmermanni współwystępuje z C. suaveolens na pogórzu i w górach, lecz jest przez tego ostatniego wypierany z żyznych nizin. 